\title{
Measuring Workload Among Health Education Faculty
}

\author{
Joan E. Cowdery ${ }^{1}$ \& Austin Agho ${ }^{2}$ \\ Eastern Michigan University \\ ${ }^{2}$ University of Michigan
}

\begin{abstract}
Legislation nationwide has mandated millions in funding cuts to state funded universities over the past several years. Additionally, university administrators frequently find themselves in the position to quantify faculty workload and productivity. The purpose of the study was to assess methodologies used by a national sample of universities to determine and assign faculty workload within health education programs. Methods included a cross-sectional descriptive study conducted utilizing a mailed survey to 106 department chairs or program directors of Health Education programs at various universities across the country. Results showed that the majority (87\%) of health education programs reported using credit hours as a measure of faculty workload (rather than contact hours). For undergraduate health education faculty 12 credit hours was the typical teaching load for $54 \%$ of respondents while $35 \%$ taught nine or less credit hours. For graduate health education faculty $48 \%$ had a full time teaching load of nine hours or less while $37 \%$ reported 12 credit hours as a full time load. At the undergraduate level, administrators allocate the majority of faculty time for teaching (61\% of effort) while at the graduate level the effort allocation was slightly shifted toward research with teaching occupying $58 \%$ of faculty time. It is anticipated that the results of this study will assist faculty and administrators in making informed decisions regarding faculty workload assignments.
\end{abstract}

(c) 2007 Californian Journal of Health Promotion. All rights reserved.

Keywords: Faculty workload, health education, credit hours, higher education administration

Legislation nationwide has mandated millions in funding cuts to state funded universities over the past several years. Additionally, university administrators frequently find themselves in the position to quantify faculty workload and productivity. In an effort to assist administrators in making informed decisions regarding faculty workload assignments the following study was initiated. The purpose of the study was to assess methodologies used by a national sample of universities to determine and assign faculty workload within health education programs.

The student credit hour has been an integral component of higher education for over a century. In a review of the history of the student credit hour, Shedd (2003) describes the invention of the credit hour as a tool for smoothing transitions from high school to college. This concept was reinforced by multiple foundations including the Carnegie Foundation for the Advancement of Teaching, to encourage the adoption of business models including unitcost analysis in higher education. Initially a measure of student learning the credit hour evolved into a measure of faculty time. Although the Carnegie unit was originally devised by a committee appointed by the National Education Association, the Carnegie foundation played a key role in the dissemination and adoption of the unit. In an effort to calculate eligibility for the retirement pensions provided by Andrew Carnegie the Carnegie unit was defined and accepted in 1909 (Shedd, 2003). The following year Morris L. Cooke developed a formula to estimate the cost and output of teaching and research to measure the efficiency and productivity of education institutions. Cooke defined a student hour as "one hour of lectures, of lab work, or recitation room work, for a single pupil” (Barrow, 1990, p. 70). This enabled relative faculty workloads to 
be calculated and was used by all colleges applying for the Carnegie Foundation pension system. As public educational institutions were increasingly pressured to justify their productivity the student hour became the basic measure of production (Shedd, 2003).

For decades the credit hour was used primarily as a measure of workload specific to teaching instruction. Ehrlich (2003) posits that although the credit hour may work well enough when lectures and the fifty-minute hour predominate, the application of such a rigid measure of faculty work may serve to limit innovation in teaching. This in addition to it not being applicable to the measure of additional faculty responsibilities such as research and service. Historically issues have arisen in areas of interdisciplinary teaching, team teaching, and more recently the use of technology including on-line teaching and the incorporation of service learning into the student experience.

Originally developed in 1969 and revised in 2000, The American Association of University Professors (AAUP) Faculty Workload Statement states that the maximum teaching load for effective instruction at the undergraduate level is a teaching load of twelve hours per week and a load of nine hours per week for instruction at the graduate level (AAUP Staff, 2000).

External pressure on colleges and universities for full disclosure regarding faculty productivity is not going away any time soon (Middaugh, 2002). Although some states have managed to escape legislative interference for now, not all institutions have been so fortunate. A 1996 AAUP report found that 21 states had some kind of mandate related to faculty workload (Euben, 2003). Mandates vary from requiring annual reporting on such issues as number of hours spent by faculty members advising students, and the percentage of lower division courses taught by senior professors to mandates that full-time faculty members of state universities who are paid entirely from state funds teach at least 12 contact hours per week (Winkler, 1992). According to Porter \& Umbach, one of the most salient policy issues in higher education has been the regulation of faculty work (Porter \&
Umbach, 2001). Historically, faculty workload is examined either due to the political climate, in order to facilitate collective bargaining agreements for unionized faculty, as a consequence of budgetary issues or in response to the lay media's request for accountability of tax payer dollars. Although a fair amount of discussion has occurred in the lay press, surprisingly little has been published in academic publications. The few studies which have been published deal almost exclusively with business management education and no studies were found that examined faculty workload in health education (Comm \& Mathaisel, 2003; Lau, 1996). In an attempt to address this void and to provide administrators with comparison data, this study of faculty workload in health education was undertaken.

\section{Methodology}

This was a cross-sectional descriptive study conducted to assess methodologies used by a national sample of universities to determine and assign faculty workload in health education programs. Human subjects approval was obtained from the university human subject committee.

\section{Sample}

A total of 106 surveys were distributed by mail to department chairs or program directors of Health Education programs at various universities across the country. Programs and contact people were identified through the use of discipline specific program directories and a review of university web sites.

\section{Data Collection}

For the purpose of data collection a 21 item survey instrument was developed. The survey was designed to collect data on a number of factors including institutional type (location, funding, Carnegie classification, etc.) types of programs offered, number of students and faculty, and measures of workload. The instrument was internally pre-tested and pilot tested among various administrators.

\section{Carnegie Classification}

The Carnegie Classification of Institutions of Higher Education is a taxonomy of U. S. higher 
education institutions that was developed in the early 70's. The purpose of which was to identify categories that would be relatively homogeneous with respect to the functions of the institutions. Although the criteria for classification takes into account many factors, the primary components have historically been the amount of federal research dollars an institution brings in and the types and number of degrees granted (McCromick, 2000). In 2000, the classification system was modified slightly and institutions were reclassified based on their degree-granting activity from 1995 to 1998. Because many University personnel are not familiar with the new classifications, for the purpose of this study the traditional classifications were used. The primary change was the reduction of Doctoral degree granting institutions from four categories to two. Universities are now classified based on the number of doctoral degrees granted and the number of disciplines for which doctoral degrees are available. The institutions sampled for this study were distributed across Carnegie classifications with 56\% identified as Research or Doctoral Universities and 34\% as Master's level institutions (see Table 3).

\section{Data Analysis}

Survey data was entered manually and all analysis was done using SPSS 10.0 for Mac. Descriptive statistics including frequency distributions, means and standard deviations were conducted on all variables.

\section{Results}

Of the 106 initial surveys, 30 surveys were completed and included in the final analysis for a response rate of $28.3 \%$. Of the 30 institutions responding to the survey, 53\% were in urban settings and $90 \%$ were public (see Table 1 ). $31 \%$ designated a Carnegie Classification of Research University I (see Table 1 ).

Table 1

Institutional Characteristics of Study Sample $(\mathrm{N}=30)$

\begin{tabular}{|l|c|c|}
\hline \multicolumn{1}{|c|}{ Institutional Characteristics } & Frequency & Percent \\
\hline Location & & \\
\hline Rural & 10 & 33.3 \\
\hline Urban & 16 & 53.3 \\
\hline Suburban & 4 & 13.3 \\
\hline Funding Type & 3 & \\
\hline Private & 27 & 90.0 \\
\hline Public & & \\
\hline Carnegie Classification & 9 & 31.0 \\
\hline Research University I & 2 & 6.9 \\
\hline Research University II & 7 & 24.1 \\
\hline Doctoral University I & 1 & 3.5 \\
\hline Doctoral University II & 5 & 17.2 \\
\hline $\begin{array}{l}\text { Masters (Comprehensive) Colleges \& } \\
\text { Universities I }\end{array}$ & 4 & 13.8 \\
\hline $\begin{array}{l}\text { Masters (Comprehensive) Colleges \& } \\
\text { Universities II }\end{array}$ & 1 & 3.4 \\
\hline Baccalaureate (Liberal Arts) Colleges I & & \\
\hline
\end{tabular}

Of the health education programs that responded to the survey, many had multiple programs within their departments and schools. The data presented in Table 2 illustrates the number of respondents who stated that they offered the following degrees at the identified discipline 
levels (undergrad, master's, doctorate). Within each level the percent is a reflection of the percentage of the total programs offered at that level. The majority of degrees offered were B.S. (58\%) and M.S. (48\%) degrees.

\section{Faculty}

The majority of health education faculty work on a semester calendar (93\%) and hold ninemonth appointments (65\%) (see Table 3).

Table 2

Degree programs offered by institutions with health education programs

\begin{tabular}{|l|c|c|}
\hline Degree Programs & Frequency & Percent \\
\hline Programs Offering Undergraduate Degrees & 28 & \\
\hline Total degrees offered & 45 & \\
\hline B.S. & 26 & 57.7 \\
\hline B.A. & 9 & 20.0 \\
\hline B.S.N. & 10 & 22.2 \\
\hline Programs Offering Master's Degrees & 29 & \\
\hline Total degrees offered & 46 & \\
\hline M.S. & 22 & 47.8 \\
\hline M.A. & 8 & 17.4 \\
\hline M.P.H. & 8 & 17.4 \\
\hline Medicine & 1 & 2.2 \\
\hline M.S.N. & 7 & 15.2 \\
\hline Programs Offering Doctorate Degrees & 7 & \\
\hline Total degrees offered & 6 & \\
\hline Ph.D. & 4 & 66.6 \\
\hline D.P.T. & 2 & 33.3 \\
\hline & & \\
\hline & & \\
\hline
\end{tabular}

*Degree totals do not add up to program totals owing to programs that offer multiple degrees.

Table 3

Health education faculty appointments by academic calendar and length of appointment

\begin{tabular}{|c|c|c|}
\hline & Frequency & Percent \\
\hline Academic Calendar & & \\
\hline Semester & 27 & 93.1 \\
\hline Trimester & 1 & 3.4 \\
\hline Quarter & 1 & 3.4 \\
\hline Length of Appointment & & \\
\hline 9-month & 22 & 64.7 \\
\hline 10-month & 7 & 20.6 \\
\hline 12-month & 5 & 14.7 \\
\hline
\end{tabular}




\section{Faculty Workload}

The majority (87\%) of health education programs reported using credit hours as a measure of faculty workload. For undergraduate health education faculty, 12 credit hours was the typical teaching load for $54 \%$ of respondents while $35 \%$ taught nine or less credit hours. For graduate health education faculty, $48 \%$ had a full time teaching load of nine hours or less while $37 \%$ reported 12 credit hours as a full time load.

Table 4

Workload measure for health education faculty

\begin{tabular}{|l|c|c|}
\hline Type of Hours & Frequency & Percent \\
\hline Course Credit Hours & & \\
\hline Contact Hours & 27 & 87.1 \\
\hline \# Credit Hours - Full-Time UG Teaching Load & 4 & 12.9 \\
\hline 3 & & \\
\hline 6 & 0 & 0 \\
\hline 9 & 3 & 11.5 \\
\hline 12 & 6 & 23.1 \\
\hline 15 & 14 & 53.8 \\
\hline other & 2 & 7.7 \\
\hline \# Credit Hours - Full-Time G Teaching Load & 1 & 3.8 \\
\hline 3 & & \\
\hline 6 & 0 & 0 \\
\hline 9 & 4 & 14.8 \\
\hline 12 & 9 & 33.3 \\
\hline 15 & 10 & 37.0 \\
\hline other & 1 & 3.7 \\
\hline
\end{tabular}

\section{Faculty Time Distribution}

At the undergraduate level, administrators allocate the majority of faculty time for teaching (61\% of effort) with effort toward research ranking second (23\%) and service third at $17 \%$. An additional $5 \%$ on average is allocated for administrative and other miscellaneous duties. At the graduate level the effort allocation was slightly shifted toward research with teaching occupying $58 \%$ of faculty time, research $25 \%$, and service just under $16 \%$.

Table 5

Faculty Time Distribution

\begin{tabular}{|c|c|c|c|}
\hline Level & N & Mean (\%) & Std. Deviation +/- \\
\hline Dedicated Time (\%)- Undergraduate & & & \\
\hline Teaching & 26 & 60.88 & 18.93 \\
\hline Research & 24 & 22.65 & 12.70 \\
\hline Service & 24 & 17.44 & 8.49 \\
\hline Other Duties (administration etc.) & 11 & 5.27 & 9.08 \\
\hline
\end{tabular}




\begin{tabular}{|l|c|c|c|}
\hline Level & N & Mean (\%) & Std. Deviation +/- \\
\hline Dedicated Time (\%)- Graduate & & & \\
\hline Teaching & 26 & 57.62 & 19.03 \\
\hline Research & 24 & 25.15 & 11.22 \\
\hline Service & 25 & 15.74 & 8.86 \\
\hline Other Duties (administration etc.) & 12 & 4.83 & 8.79 \\
\hline
\end{tabular}

\section{Discussion}

The predominant limitation of this study was the relatively low response rate and subsequent participation of health education department administrators. However, it is vital that data be established and documented regarding the calculation and distribution of faculty workload within departments employing health education faculty. Too often faculty and administrators are required to make decisions regarding faculty workload assignments without any standards of comparison. By examining a sampling of methodologies used by universities nationwide to quantify faculty workload both faculty and administrators will be assisted in making informed decisions regarding faculty workload assignments.

\section{References}

Shedd, J. M. (2003). The history of the student credit hour. New Directions for Higher Education, 122, 512.

Barrow, C. W. (1990). Universities and the capitalist state: Corporate liberalism and the reconstruction of American higher education, 1894-1928. Madison, WI: University of Wisconsin Press.

Thomas, E. (2003). The credit hour and faculty instructional workload. New Directions for Higher Education, 122, 45 - 55.

American Association of University Professors Staff. (2000). Interpretive comments on the statement of faculty workload. Academe, 86(3), 69-72.

Middaugh, M. (2002). Faculty productivity, different strategies for different audiences. Planning for Higher Education, 30(3), 34-43.

Euben, D. (2003). Lives in the Balance: Compensation, workloads and program implications. American Association of University Professors. Legal Issues in Higher Education. 13th Annual Conference, 10-13.

Winkler, A. (1992). The faculty workload question. Change, 24, 36-41.

Porter, S., \& Umbach, P. (2001). Analyzing faculty workload data using multilevel modeling. Research in Higher Education, 42, 171-196.

Comm, C., \& Mathaisel, D. (2003). A case study of the implications of faculty workload and compensation for improving academic quality. The International Journal of Educational Management, 17(4/5), 200.

Lau, R. (1996). Evaluating faculty workload: An application of process control charts with supplementary run rules. Journal of Education for Business, 72, 94-97.

McCormick, A. (2000). The 2000 Carnegie classification: Background and description. Retrieved September 24, 2004, from http://www.carnegiefoundation.org

\section{Acknowledgements}

The authors wish to thank Carrie George, Graduate Assistant, Department of Health Sciences and Administration, University of Michigan, Flint for all of her assistance in the data collection process of this project. 
This research was supported by a grant from the Office of Graduate Programs and the Office of Research, University of Michigan, Flint.

\author{
$\underline{\text { Author Information }}$ \\ Joan E. Cowdery, PhD* \\ Assistant Professor, Health Education \\ School of Health Promotion \& Human Performance \\ Eastern Michigan University \\ 318 Porter Building \\ Ypsilanti, MI 48197 \\ Ph.: 734-487-7120 x2698 \\ Fax.: 734-487-2024 \\ E-Mail :jcowdery@emich.edu \\ Austin Agho, $\mathrm{PhD}$ \\ Dean \\ School of Health Professions and Studies \\ University of Michigan, Flint \\ Flint, MI 48502 \\ * corresponding author
}

